\title{
Article \\ Evaluation of Clove Extract for Drug Therapy of Ciliate Infection in Coral (Goniopora columna)
}

\author{
Tah-Wei Chu ${ }^{1,+}$, Chiu-Min Cheng $\left.{ }^{1,+} \mathbb{(}\right)$, Yu-Rong Cheng ${ }^{2}$, Cheng-Di Dong ${ }^{3} \mathbb{D}$, Chih-Hung Chuang ${ }^{4} \mathbb{D}$, \\ Chih-Hung Pan ${ }^{1}$, Wei-Ting Sun ${ }^{1}$ and De-Sing Ding ${ }^{1, *(\mathbb{B})}$
}

1 Department and Graduate Institute of Aquaculture, National Kaohsiung University of Science and Technology, Kaohsiung 811, Taiwan; twchu@nkust.edu.tw (T.-W.C.); cmcheng@nkust.edu.tw (C.-M.C.); pc116605t@yahoo.com.tw (C.-H.P.); 1051537103@nkust.edu.tw (W.-T.S.)

2 Department of Fisheries Production and Management, National Kaohsiung University of Science and Technology, No. 142, Haijhuan Rd., Nanzih District, Kaohsiung 811, Taiwan; yrcheng@nkust.edu.tw

3 Department of Marine Environmental Engineering, National Kaohsiung University of Science and Technology, Kaohsiung 811, Taiwan; cddong@nkust.edu.tw

4 Department of Medical Laboratory Science and Biotechnology, College of Health Sciences, Kaohsiung Medical University, Kaohsiung 807, Taiwan; a4132600@gmail.com

* Correspondence: 1041750102@nkust.edu.tw

+ These authors contributed equally to this work.

check for

updates

Citation: Chu, T.-W.; Cheng, C.-M.; Cheng, Y.-R.; Dong, C.-D.; Chuang, C.-H.; Pan, C.-H.; Sun, W.-T.; Ding, D.-S. Evaluation of Clove Extract for Drug Therapy of Ciliate Infection in Coral (Goniopora columna). Biology 2022, 11, 280. https://doi.org/ 10.3390/biology11020280

Academic Editor: Nicholas S. Foulkes

Received: 29 December 2021 Accepted: 8 February 2022

Published: 10 February 2022

Publisher's Note: MDPI stays neutral with regard to jurisdictional claims in published maps and institutional affiliations.

Copyright: (C) 2022 by the authors. Licensee MDPI, Basel, Switzerland. This article is an open access article distributed under the terms and conditions of the Creative Commons Attribution (CC BY) license (https:// creativecommons.org/licenses/by/ $4.0 /)$.
Simple Summary: In recent years, studies have found that coral infectious diseases are gradually spreading. Ciliate disease poses a serious threat to corals, and infected corals will fester and die within a short period of time. Clove is a traditional Chinese medicine. In this study, Clove extract was used to evaluate the treatment of ciliate diseases to achieve safety and to reduce the stress response of corals. Studies have shown that 1500 ppm clove extract can effectively treat ciliate parasitism, and does not affect coral zooxanthellae, chlorophyll a, or stress response. This extract has been successfully applied to a Taiwan coral king coral farm, which will have great significance for large-scale coral aquaculture.

\begin{abstract}
In recent years, ciliate infections have caused serious casualties to corals in the ocean Infected corals die within a short period of time, which not only poses a threat to wild coral reefs, but also has a major impact on large scale aquaculture of coral. Clove is a kind of Chinese medicine with antifungal, antibacterial, antiviral, insecticidal, and other functions. Clove is a natural product. If it can be used in the treatment of coral ciliates, it will reduce this threat to the environment. The clove extract was diluted with sterile seawater to 500 ppm, 1500 ppm, 2500 ppm, 5000 ppm, 7500 ppm, and $10,000 \mathrm{ppm}$ to carry out virulence test on ciliates. The results show that the $\mathrm{LC}_{50}$ value is $1500 \mathrm{ppm}$, which can cause the death of ciliates in 10 min without causing significant changes in G. columna SOD, CAT, chlorophyll a, and zooxanthellae. In addition, observation of tissue slices revealed that no ciliates and vacuum were found in the G. columna tissue after $10 \mathrm{~min}$ of medicated bathing. In summary, 1500 ppm of clove extract can be used for the treatment of coral ciliates.
\end{abstract}

Keywords: clove; ciliate; Goniopora columna; antioxidant enzymes; treatment

\section{Introduction}

Global climate change, sedimentation, nutrient enrichment, and ocean warming have caused some disease outbreaks in coral, leading to death [1,2]. Bourne et al. (2008) [3] found that coral infectious diseases have gradually continued to spread in recent years. At present, ciliates have been found to parasitize corals and cause large areas of bleaching and death in the Caribbean Sea, the Great Barrier Reef, and the Pacific Ocean, which are important coral reef areas in the world [3,4]. To date, the diseases that have been found to cause coral infections include white band disease (WBD), white plague (BP), brown jelly syndrome (BJS), brown band syndrome (BrB), skeletal eroding band (SEB), etc., [5-7]. 
The BJS, BrB, and WS diseases are all caused by ciliate infection, and the infected coral tissues become pathological and produce a characteristic jelly-like substance $[8,9]$. Coral infection with ciliate disease will cause tissue bleaching and ulceration at the initial stage, which has a high mortality rate [10]. In addition, due to the booming global aquarium ornamental trade in recent years, corals infected with ciliates may also be transported to aquariums around the world [10]. This may cause the spread of ciliate infections to accelerate, and effective prevention and treatment will curb the threat of ciliates to corals. According to previous studies, it has been found that folliculinid ciliate (Halofolliculina corallasia) infection can cause diseased coral tissues to produce speckled black bands [6]. The BrB infection has caused serious casualties on the three corals of the Great Barrier Reef, Acroporidae, Pocilloporidae, and Faviidae [11]. Halofolliculina sp. can invade and parasitize through damaged coral tissues, causing a coral to fester and die [12]. Therefore, if the coral is bitten by a fish or Acanthaster planci, it may cause Halofolliculina sp. invasive infection [13]. This has a considerable impact on the sustainable development of coral reefs and the development of large-scale coral aquaculture. Porpostoma guamensis will swallow coral tissues, zooxanthellae, and eggs, causing brown bands to form on the coral [14]. Coral ciliate infection is one of the most important diseases affecting the survival of coral reefs. Corals infected with ciliates can undergo rapid tissue decay and death [14,15]. There are few studies on the pathogenic potential and treatment of corals caused by ciliate disease. Our recent research has found that Philaster lucinda is a potential parasite of corals. It feeds on coral tissues and zooxanthellae. After infection, it will cause corals to die quickly. Its treatment and prevention are very important [10]. Sweet and Séré, (2016) found that corals infected with ciliates (P. lucinda) die within $24 \mathrm{~h} \mathrm{[16].} \mathrm{Page} \mathrm{and} \mathrm{Willis} \mathrm{found} \mathrm{that} \mathrm{the}$ Acropora muricata tissue ulceration rate after $P$. lucinda infection is $\sim 2 \mathrm{~mm} /$ day, which means the coral will die shortly after infection [17]. Coral infection by P. lucinda will cause coral bleaching and death within $72 \mathrm{~h}$ [10]. Previous research mainly focused on the investigation of diseases in wild corals. Therefore, effective prevention and treatment of coral ciliate diseases is an important area of research.

Clove (Syzygium aromaticum) is a Chinese medicine, a terrestrial plant, with a natural fragrance, and it is also a spice $[18,19]$. It has antiseptic, antifungal, antibacterial, antiviral, and anticancer activities [18]. Toxic at high concentrations, it will cause tissue damage and hepatotoxicity [20]. In addition, the heterogeneous distillate made from crushed clove, commonly known as clove oil, has the function of anesthesia and treatment of toothache [21]. Clove oil is used to sedate fish during transport or surgery [22]. The active substance contained in clove oil is eugenol (4-allyl-2-methoxyphenol), which accounts for about $70-95 \%$, and the remaining $5-30 \%$ is made up of eugenol acetate and kariofilen$5[18,21,23]$. In aquaculture applications, clove oil is often used as an anesthetic or as an alternative to cyanide for fishing coral reef fish $[18,24]$. Previous research indicated that limited amounts of clove oil solution are unlikely to harm Pocillopora damicornis [19]. At present, clove oil is used to kill ciliates in the purification and cultivation of microalgae [25]. Therefore, this study explores whether natural clove extract can be used to kill ciliates without harming corals.

In this experiment, the antioxidant enzymes superoxide dismutase (SOD) and catalase (CAT) were used to evaluate the stress response of corals under treatment. The biological metabolism requires $\mathrm{O}_{2}$, and organisms produce free radicals and reactive oxygen species (ROS). The stress response can lead to a gradual increase in coral ROS, causing coral bleaching or death [26,27]. Disease and environmental stress can induce ROS elevation, causing oxidative damage in the coral-zooxanthellae symbiotic system [28-31]. Corals respond to stress by producing antioxidant enzymes (SOD and CAT) to suppress ROS. The defense mechanism of cells against the formation of oxygen radicals involves enzymes such as SOD and CAT to act in concert to inactivate superoxide radicals and hydrogen peroxide. This prevents the formation of the most reactive form of ROS, the hydroxyl radical, and subsequent cellular damage [10,31]. SOD catalyzes the dismutation of superoxide into oxygen and hydrogen peroxide, and CAT is responsible for inactivating hydrogen peroxide 
into water and oxygen [10]. These enzymes are responsible for detoxifying ROS, and their elevated activities indirectly indicate an increased production of ROS in corals as a result of disease or environmental stresses such as poor water quality, UV radiation, irradiance, and temperature [28]. Cheng et al., (2021) [10] pointed out that G. columna infections with ciliates can cause significant changes in superoxide dismutase and catalase in the body. Therefore, this study uses superoxide dismutase and catalase changes as the stress response of $P$. lucinda infection and clove extract treatment of coral cells.

This study hopes to use safer and natural ingredients to treat ciliate diseases. If corals can be soaked in clove extract for a long time without damaging the coral tissues, it will be of very helpful for the sustainability of coral reefs and large-scale aquaculture of $G$. columna. The ciliates (P. lucinda) in this experiment were purified and cultured from coral. After infecting the G. columna with ciliates, clove extract was used for treatment to observe changes in G. columna morphology, chlorophyll a content, number of zooxanthellae, tissue and survival, and to detect antioxidant enzyme activity (superoxide dismutase and catalase) to determine the stress response of the coral after treatment, in order to evaluate whether the clove extract can be used as a treatment for coral ciliates.

\section{Materials and Methods}

\subsection{Experiment 1, Evaluation of Toxicity and Coral Drug Tolerance of Clove Extract on Coral Ciliates Disease}

\subsubsection{Purification and Identification of Ciliates}

The ciliates used in this experiment were from infected G. columna coral for pure culture. Refer to $[10,16]$ for the identification of ciliates. Total DNA of ciliates was sampled from infected corals using a genomic DNA isolation kit (Protech Technology Enterprise Co., Ltd., Taipei, Taiwan). Amplification of universal eukaryotic $18 \mathrm{~S}$ rRNA gene was performed using the primers $4617 \mathrm{f}$ and $4618 \mathrm{r}$ [16]. The operation method of PCR was as follows: the sample was preheated at $95^{\circ} \mathrm{C}$ for 3 min for 35 cycles $\left(95^{\circ} \mathrm{C} ; 30 \mathrm{~s}, 55^{\circ} \mathrm{C} ; 30 \mathrm{~s}\right.$, and $72{ }^{\circ} \mathrm{C}$; $1 \mathrm{~min}$ ), then $72^{\circ} \mathrm{C} ; 5 \mathrm{~min}$. Next, $1 \mathrm{uL}$ of the PCR product was used for the nested PCR with the ciliate-specific primers 384f-cil and 1147r-cil [16]; the annealing temperature of the PCR was $60^{\circ} \mathrm{C}$. The PCR product was cloned into pCR-Blunt (Zero Blunt cloning kit; Invitrogen) and sequenced by a biotech company. Gene sequence alignment was performed using the Basic Local Alignment Search Tool. The pure ciliates were a pure culture in $50 \mathrm{~mL}$ sterile saltwater and fed with coral polyps daily. We used a microscope (Leica DM500, 400×) to observe zooxanthellae in the ciliates every $24 \mathrm{~h}$. If the zooxanthellae were digested in the body, G. columna polyps were added. We changed the water once a week during the cultivation period. Please refer to Table 1 for the water quality parameters. After $48 \mathrm{~h}$ of incubation, we used a microscope (Leica DM500) at 100 $\times$ magnification to calculate the number of ciliates using a hemocytometer [10].

Table 1. The water quality conditions in the study.

\begin{tabular}{ccc}
\hline Water Quality Conditions & Ciliates & Coral \\
\hline Temperature $\left({ }^{\circ} \mathrm{C}\right)$ & $26.0 \pm 0.5$ & $26.0 \pm 0.5$ \\
pH & $8.0 \pm 0.5$ & $8.0 \pm 0.5$ \\
Dissolved oxygen $(\mathrm{ppm})$ & $6.00 \pm 0.05$ & $6.00 \pm 0.05$ \\
Nitrous acid $(\mathrm{ppm})$ & $0.01 \pm 0.01$ & $0.01 \pm 0.01$ \\
Nitric acid $(\mathrm{ppm})$ & $0.05 \pm 0.02$ & $0.02 \pm 0.01$ \\
Calcium $(\mathrm{ppm})$ & $425 \pm 40.12$ & $455 \pm 10.32$ \\
Magnesium $(\mathrm{ppm})$ & $1324 \pm 63.21$ & $1360 \pm 52.21$ \\
Ammonia nitrogen $(\mathrm{ppm})$ & $0.01 \pm 0.05$ & $0.01 \pm 0.05$ \\
Phosphate $(\mathrm{ppm})$ & $0.01 \pm 0.01$ & $0.01 \pm 0.01$ \\
\hline
\end{tabular}

Values are expressed as means \pm SDs $(n=3)$.

\subsubsection{Clove Extract}

The extraction method of this experiment refers to Cortés-Rojas et al., 2014. After grinding $50 \mathrm{~g}$ of dried clove buds, we put them in an Erlenmeyer flask and used 70\% $(v / v)$ 
ethanol for $48 \mathrm{~h}$ of extraction. The ratio of plant to solvent was $1 / 10(w / v)$. The extractive solution was concentrated in a rotary evaporator using a vacuum pressure of $600 \mathrm{mmHg}$ at a maximum temperature of $55^{\circ} \mathrm{C}$. After the extraction was completed, the extract was freeze-dried (Boyer et al., 2009) [32]. We found that using ethanol as a solvent in Clove oil caused coral bleaching. Therefore, we used sterile seawater as a solvent. The use of seawater dilution can prevent errors caused by osmotic pressure. The concentrations of clove extract were 500, 1500, 2500, 5000, 7500, and 10,000 ppm, no medication was used on control group C.

\subsubsection{Coral Samples}

G. columna was taken from Taiwan Coral King Coral Farm of Taiwan (CITES legal coral farm, CITES number FTS507W0153796). The coral culture method refers to [33], and a total of hundred colonies of the corals were kept in a tank $\left(60 \times 35 \times 30 \mathrm{~cm}^{3}\right)$ with a recirculating filtered seawater system. After two months of self-repair and acclimation, healthy $G$. columna were cut into 5 polyps per colony, and then stuck on the rough cornerstone with coral glue; each group contained ten colonies. Each experiment was repeated in triplicate, and each group contained thirty colonies $(n=30)$. For the water quality parameters for farming corals, please refer to Table 1.

\subsubsection{Ciliate Toxicity Test}

In this experiment, refer to [10,34]. Cultured coral ciliates were microscopically observed for viability and health and counted using hemocytomete. The density of ciliates used in this experiment was 1 cell mL $\mathrm{m}^{-1}$. Chen et al. (2021) [10] found that, at this density, infection can cause G. columna to fester and die $72 \mathrm{~h}$ after infection. Therefore, the clove extract was diluted with sterile saltwater to $500,1500,2500,5000,7500$, and 10,000 ppm to conduct toxicity tests on the P. lucinda, the death time and number of ciliates were recorded, and the experiment ended when the ciliates completely died. Referring to the method of Cheng et al. [10], we use the $\mathrm{LC}_{50}$ value to represent the $50 \%$ lethal concentration of ciliates.

\subsubsection{Evaluation of Coral's Drug Tolerance to Clove Extract}

In this experiment, we refer to Ding et al. [33] for G. columna aquaculture methods. The specimens were maintained and fed in a recirculating filtered tank $\left(60 \times 35 \times 30 \mathrm{~cm}^{3}\right)$ with a saltwater system, using a beaker $(500 \mathrm{~mL})$ filled with sterile saltwater for the experimental grouping. The $500 \mathrm{~mL}$ beaker was put in a recirculation filtration and constant temperature tank to ensure consistent water conditions. After observation for $2 \mathrm{~h}$, we waited for the coral polyps to fully extend before starting the test. The ciliate toxicity test results showed that $500 \mathrm{ppm}$ would not cause the death of ciliates, so the tested concentrations of clove extract in this experiment were $1500 \mathrm{ppm}$ 2500, 5000, 7500 and 10,000 ppm. Samples were taken after $10 \mathrm{~min}$ and $24 \mathrm{~h}$, respectively, for zooxanthellae, chlorophyll a, polyp length, survival rate and two antioxidant enzyme (SOD and CAT) activity tests to assess whether long-term dipping would cause a coral stress response.

\subsubsection{Analysis of Two Antioxidant Enzymes}

The detection method of this experiment refers to [10,35], the G. columna tissue was homogenized and we added nine times the volume of ice-cold extraction buffer to dissolve (20 mM phosphate buffer, $0.1 \%(v / v)$ Triton X-100; $\mathrm{pH} 7.4,1 \mathrm{mM}$ EDTA). The coral crude extract was sonicated at low temperature ( $3 \mathrm{~s}$ each, 5 times), centrifuged $(12,000 \times g, 5 \mathrm{~min}$, $4{ }^{\circ} \mathrm{C}$ ) and used as a coral tissue solution for enzyme and protein determination.

\subsubsection{Superoxide Dismutase and Catalase Detection}

The detection method of SDO refers to Higuchi et al. (2008) [31] and Chen et al. (2021) [10], and we used assayed spectrophotometrics to measure it. Each treatment group first used bovine erythrocytic (Sigma) to prepare the active standard. All measurements were performed at a constant temperature of $25^{\circ} \mathrm{C}$. Protein content was measured using 
the Bradford assay [36]. CAT detection refers to Main, Ross, and Bielmyer. (2010) [37] and Chen et al. (2021) [10], using Sigma commercial reagents. First, we added the coral tissue solution $(15 \mathrm{~mL})$ to the tube, added reagents and centrifuged, and took the supernatant as a test sample. Finally, absorbance was measured using OD $520 \mathrm{~nm}$. We refer to the calculation formula of Cheng et al. (2021) [10] for CAT calculation.

\subsubsection{Protein Concentrations}

The coral specimens were homogenated and sonicated, and protein concentrations were measured using a commercially available reagent Bradford protein assay kit (Amresco, Solon, $\mathrm{OH}, \mathrm{USA}$ ), with bovine serum albumin serving as the protein standard.

\subsubsection{Analysis of Zooxanthellar Density and Chlorophyll a}

This experiment was performed according to the methods of Levy et al. [38] and Cheng et al. [10]. First, we homogenized the coral tissue and then used the blood cell counter to calculate the zooxanthellae. The density of zooxanthellae represented the content of each polyp. The detection method of chlorophyll a was based on the methods of Levy et al. [38] and Titlyanov et al. 2001 [39]. We took $0.5 \mathrm{~g}$ of coral tissue for homogenization, added $10 \mathrm{~mL}$ (90\% acetone), and let it stand for $24 \mathrm{~h}$ under completely dark conditions at a constant temperature of $4{ }^{\circ} \mathrm{C}$. Finally, measurements were made with absorbance OD 630 and $664 \mathrm{~nm}$. The concentration calculation was carried out with reference to the calculation formula of Jeffrey and Humphrey [40].

\subsection{Experiment 2, Clove Extract for Treatment of Coral Ciliates Disease}

\subsubsection{Ciliate Disease Treatment Test}

In experiment 1 , it was known that the $\mathrm{LC}_{50}$ of clove extract against ciliates is $1500 \mathrm{ppm}$ and that it can cause complete death within $10 \mathrm{~min}$. Therefore, in the study of the ciliate disease treatment and drug tolerance of coral, 1500, 2500, 5000, 7500 and 10,000 ppm were selected as test concentrations. No medication was used on control group C. This experiment refers to Cheng et al. (2021) [10]. After the corals were infected by ciliates, they were dipped in different clove extract concentrations for $10 \mathrm{~min}$, and then replaced in sterilized seawater. After 72 h, we referred to Levy et al. (2003) [38] and Chen et al. (2021) [10] for the method to judge the change in coral morphology, and the survival, chlorophyll a, zooxanthellae number, antioxidant enzymes superoxide dismutase and catalase were measured to evaluate the effect of drug treatment on the coral. After the experiment, the seawater in the beaker was centrifuged, the supernatant liquid was removed, and the ciliates in the saltwater were calculated using a hemocytometer.

\subsubsection{Histology Observation}

After the treatment experiment was over, G. columna tissues were fixed with $4 \%$ formalin for $48 \mathrm{~h}$, then soaked with 5\% formic acid until the bones were completely dissolved, and then dehydrated with alcohol for paraffin embedding and tissue sectioning. Routine tests were carried out for histology, tissue sectioning, and staining with hematoxylin and eosin (H and $\mathrm{E})[14,41]$.

\subsection{Statistical Analysis}

Data were obtained from two independent experiments, and the final results were presented as the mean \pm standard deviation (SD). One-way analysis of variance and Duncan's multiple range test were used to determine the statistical significance for survival, SOD, CAT of G. columna, as well as its chlorophyll a and zooxanthellar density content. A $p$-value of $<0.05$ was considered significant. All statistical analyses were performed using IBM SPSS statistics 20. 


\section{Results}

\subsection{Experiment 1, Evaluation of Toxicity and Coral Drug Tolerance of Clove Extract on Coral Ciliates Disease}

\subsubsection{Toxicity Test of Clove Extract on Ciliates}

The toxicity test results for the clove extract on P. lucinda are shown in Table 2. At a poisoning time of $600 \mathrm{~s}$, the $500 \mathrm{ppm}$ concentration of clove extract did not cause death to ciliates. When the concentration was above $1500 \mathrm{ppm}$, death began to occur after $300 \mathrm{~s}$ $(61.67 \pm 5.57 \%)$, and the pathogens were completely dead by $420 \mathrm{~s}$. With $2500 \mathrm{ppm}$, they began to die at $240 \mathrm{~s}(58.33 \pm 2.89 \%)$, and the mortality rate reached $100 \%$ at $360 \mathrm{~s}$. Deaths occurred within $60 \mathrm{~s}$ for the 5000, 7500, and 10,000 ppm experiments. The mortality rates were $80.33 \pm 1.53 \%, 75.33 \pm 5.51 \%$, and $38.33 \pm 7.64 \%$, respectively. The $100 \%$ mortality of the three treatment groups all occurred within $300 \mathrm{~s}$. In conclusion, the $\mathrm{LC}_{50}$ was $1520 \mathrm{ppm}$ for clove extract, which can cause P. lucinda to die after $420 \mathrm{~s}$ of treatment.

Table 2. Inhibitory concentrations of clove extract on ciliates.

\begin{tabular}{|c|c|c|c|c|c|c|c|}
\hline \multirow[b]{2}{*}{ Sec } & \multicolumn{7}{|c|}{ Survival Rate $\%$ (Mean \pm SD) } \\
\hline & $\mathrm{C}$ & 500 ppm & 1500 ppm & $2500 \mathrm{ppm}$ & 5000 ppm & 7500 ppm & $10,000 \mathrm{ppm}$ \\
\hline 60 & $100 \pm 0.00$ & $100 \pm 0.00$ & $100 \pm 0.00$ & $100 \pm 0.00$ & $80.33 \pm 1.53$ & $75.33 \pm 5.51$ & $38.33 \pm 7.64$ \\
\hline 120 & $100 \pm 0.00$ & $100 \pm 0.00$ & $100 \pm 0.00$ & $100 \pm 0.00$ & $54.00 \pm 4.36$ & $50.00 \pm 2.65$ & $32.33 \pm 7.51$ \\
\hline 180 & $100 \pm 0.00$ & $100 \pm 0.00$ & $100 \pm 0.00$ & $100 \pm 0.00$ & $40.00 \pm 3.61$ & $40.67 \pm 1.53$ & $13.33 \pm 1.53$ \\
\hline 240 & $100 \pm 0.00$ & $100 \pm 0.00$ & $100 \pm 0.00$ & $58.33 \pm 2.89$ & $15.33 \pm 1.53$ & $11.00 \pm 1.00$ & $6.33 \pm 2.52$ \\
\hline 300 & $100 \pm 0.00$ & $100 \pm 0.00$ & $61.67 \pm 5.57$ & $16.67 \pm 2.89$ & $0.00 \pm 0.00$ & $0.00 \pm 0.00$ & $0.00 \pm 0.00$ \\
\hline 360 & $100 \pm 0.00$ & $100 \pm 0.00$ & $23.33 \pm 7.64$ & $0.00 \pm 0.00$ & $0.00 \pm 0.00$ & $0.00 \pm 0.00$ & $0.00 \pm 0.00$ \\
\hline 420 & $100 \pm 0.00$ & $100 \pm 0.00$ & $0.00 \pm 0.00$ & $0.00 \pm 0.00$ & $0.00 \pm 0.00$ & $0.00 \pm 0.00$ & $0.00 \pm 0.00$ \\
\hline 480 & $100 \pm 0.00$ & $100 \pm 0.00$ & $0.00 \pm 0.00$ & $0.00 \pm 0.00$ & $0.00 \pm 0.00$ & $0.00 \pm 0.00$ & $0.00 \pm 0.00$ \\
\hline 540 & $100 \pm 0.00$ & $100 \pm 0.00$ & $0.00 \pm 0.00$ & $0.00 \pm 0.00$ & $0.00 \pm 0.00$ & $0.00 \pm 0.00$ & $0.00 \pm 0.00$ \\
\hline 600 & $100 \pm 0.00$ & $100 \pm 0.00$ & $0.00 \pm 0.00$ & $0.00 \pm 0.00$ & $0.00 \pm 0.00$ & $0.00 \pm 0.00$ & $0.00 \pm 0.00$ \\
\hline
\end{tabular}

Values are expressed as means \pm SDs $(n=3)$

\subsubsection{The Effect of Clove Extract on G. columna Stress Response}

The tolerance of corals to clove extracts was evaluated based on the stress response of corals to clove extracts. The results of Figure 1 show that after $10 \mathrm{~min}$ of stress response, coral SOD activity increased significantly. The highest SOD activities, at 7500 and $10,000 \mathrm{ppm}$ were $5.78 \pm 0.56 \mathrm{U} / \mathrm{mg}$ protein and $5.67 \pm 0.52 \mathrm{U} / \mathrm{mg}$ protein, respectively, and the lowest of the treatment group was at $1500 \mathrm{ppm}$, which was $1.21 \pm 0.34 \mathrm{U} / \mathrm{mg}$ protein. The difference in SOD activity between the two was about 4.37 times. There was no significant difference between the SOD activity of $C$ and $1500 \mathrm{ppm}$ for $10 \mathrm{~min}$ of dipping. In addition, long-term dipping for $24 \mathrm{~h}$ showed that the SOD activity at $1500 \mathrm{ppm}$ and 2500 ppm differed by 1.25 times.

The results of the CAT are shown in Figure 1. There was no significant difference between $C$ and 1500 and $2500 \mathrm{ppm}$ in $10 \mathrm{~min}$ of treatment. The CAT activity of the $5000 \mathrm{ppm}$ treatment group began to increase significantly, and at 10,000 ppm the CAT activity reached the highest at $19.57 \pm 0.90 \mathrm{U} / \mathrm{mg}$ protein, which was 3.71 times higher than that of $1500 \mathrm{ppm}$. The 24-h treatment results show that there was no significant difference between $\mathrm{C}$ and $1500 \mathrm{ppm}$, and that $2500 \mathrm{ppm}$ was 3.58 times higher than $1500 \mathrm{ppm}$. In the treatment groups above $5000 \mathrm{ppm}$, the corals were dead, and the activity of SOD and CAT could not be detected (Table 3). Therefore, the higher the concentration or the longer the dipping time, the more significant the stress response of the corals. 


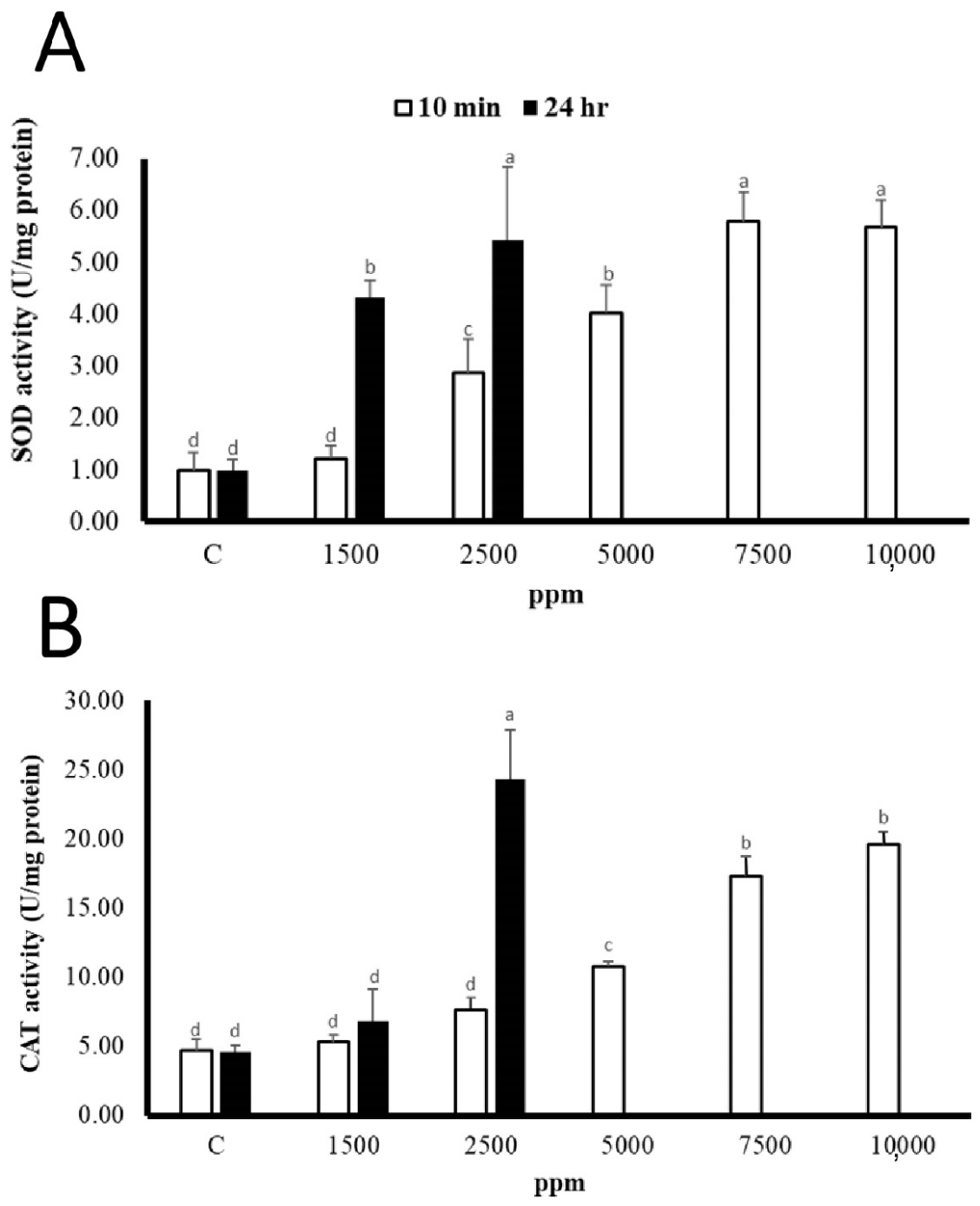

Figure 1. Clove extract response to coral stress. Different letters indicate significant differences among groups $(p<0.05)$. The values are expressed as means \pm SDs $(n=30$ colonies): (A) SOD; (B) CAT. The treatment group above 5000 ppm could not be detected due to the death of the corals.

Table 3. The effect of clove extract on coral zooxanthellae, chlorophyll a, polyp length, and survival.

\begin{tabular}{|c|c|c|c|c|c|}
\hline Time & Treatments (ppm) & $\begin{array}{c}\text { Zooxanthellae } \\
\left(\text { Cells } \times 10^{7} \mathrm{~m}^{-2}\right)\end{array}$ & $\begin{array}{l}\text { Chlorophyll } \\
\text { a }\left(\mu \mathrm{g} \mathrm{cm}^{-2}\right)\end{array}$ & $\begin{array}{l}\text { Polyp Length } \\
\text { (cm/polyp) }\end{array}$ & Survival Rate (\%) \\
\hline \multirow{6}{*}{$10 \mathrm{~min}$} & $\mathrm{C}$ & $5.10 \pm 2.54^{\mathrm{a}}$ & $45.72 \pm 5.30^{a}$ & $1.05 \pm 0.05^{\mathrm{a}}$ & $100 \pm 0.00^{a}$ \\
\hline & 1500 & $5.05 \pm 1.45^{\mathrm{a}}$ & $44.21 \pm 9.32^{\mathrm{a}}$ & $1.03 \pm 0.50^{\mathrm{a}}$ & $100 \pm 0.00^{a}$ \\
\hline & 2500 & $5.02 \pm 2.34^{\mathrm{a}}$ & $47.07 \pm 8.83^{\mathrm{a}}$ & $0.65 \pm 0.32^{b c}$ & $100 \pm 0.00^{a}$ \\
\hline & 5000 & $5.02 \pm 1.45^{\mathrm{a}}$ & $48.45 \pm 7.05^{\mathrm{a}}$ & $0.10 \pm 0.01^{c}$ & $100 \pm 0.00^{\mathrm{a}}$ \\
\hline & 7500 & $5.07 \pm 1.36^{\mathrm{a}}$ & $46.93 \pm 9.32^{a}$ & $0.10 \pm 0.01^{c}$ & $100 \pm 0.00^{\mathrm{a}}$ \\
\hline & 10,000 & $5.06 \pm 2.08^{a}$ & $47.21 \pm 7.31^{\mathrm{a}}$ & $0.10 \pm 0.02^{c}$ & $100 \pm 0.00^{\mathrm{a}}$ \\
\hline \multirow{6}{*}{$24 \mathrm{~h}$} & $\mathrm{C}$ & $5.12 \pm 0.41^{\mathrm{a}}$ & $46.03 \pm 4.83^{a}$ & $1.05 \pm 0.00^{\mathrm{a}}$ & $100 \pm 0.00^{\mathrm{a}}$ \\
\hline & 1500 & $4.53 \pm 0.21^{\mathrm{a}}$ & $43.02 \pm 3.42^{\mathrm{a}}$ & $1.03 \pm 0.50^{\mathrm{a}}$ & $90.00 \pm 0.50^{b}$ \\
\hline & 2500 & $3.21 \pm 0.41^{b}$ & $32.33 \pm 5.09^{b}$ & $0.20 \pm 0.00^{b}$ & $85.00 \pm 0.00^{c}$ \\
\hline & 5000 & $2.92 \pm 0.31^{b}$ & $24.04 \pm 6.42^{b}$ & $0.10 \pm 0.00^{c}$ & $0.00 \pm 0.00^{\mathrm{d}}$ \\
\hline & 7500 & $0.04 \pm 0.00^{c}$ & $0.90 \pm 0.00^{c}$ & $0.00 \pm 0.00^{\mathrm{d}}$ & $0.00 \pm 0.00^{d}$ \\
\hline & 10,000 & $0.04 \pm 0.00^{c}$ & $0.90 \pm 0.00^{c}$ & $0.00 \pm 0.00^{\mathrm{d}}$ & $0.00 \pm 0.00^{d}$ \\
\hline
\end{tabular}

Different letters indicate significant differences among groups in Duncan's multiple range test $(p<0.05)$. Values are expressed as means \pm SDs ( $n=30$ colonies). C: control group. 


\subsubsection{Coral Drug Tolerance Assessment}

The drug tolerance evaluation of coral after clove extract treatment for $10 \mathrm{~min}$ and $24 \mathrm{~h}$ of dipping is shown in Table 3. After $10 \mathrm{~min}$ of treatment of G. columna, the survival rate of each treatment group was $100 \%$. The polyp length of each treatment group was significantly shortened, the largest difference was the treatment group above $5000 \mathrm{ppm}$, whose polyps were shortened to $0.10 \mathrm{~cm}$. Further, polyps in the $1500 \mathrm{ppm}$ and $2500 \mathrm{ppm}$ treatment conditions were 1.05 and 1.61 times shorter than the $C$ group. The zooxanthellae of group $C$ was $5.10 \pm 2.54$ cells $\times 10^{7} \mathrm{~m}^{-2}$, which was nonsignificant compared with each treatment group. Chlorophyll a in each treatment group was also nonsignificant.

After a long period of $24 \mathrm{~h}$ of treatment, the survival rate of each treatment group was significantly reduced, and the survival rate of each group above $5000 \mathrm{ppm}$ treatment was $0 \%$. There was no significant difference between the $C$ and $1500 \mathrm{ppm}$ polyp length, while the other treatment groups had significant polyp shortening, which was reduced to $0.00 \mathrm{~cm}$ at $7500 \mathrm{ppm}$. The content of zooxanthellae and chlorophyll a in the corals showed that there was no significant difference between $C$ and $1500 \mathrm{ppm}$, and there was a significant decrease in the other treatment groups. In short, in addition to the concentration of clove extract that affects the drug tolerance of corals, dipping time can also cause corals to die.

\subsection{Experiment 2, Clove Extract for Treatment of Coral Ciliates Disease}

\subsubsection{Drug Therapy Evaluation}

According to the experimental results, Table 4 shows. P. lucinda was infected with $G$. columna, and after dipping with different concentrations of clove extract for $10 \mathrm{~min}$, after $72 \mathrm{~h}$ it was found that the survival rate of control group $\mathrm{C}$ was only $11.35 \pm 5.73 \%$, and the survival rate of other clove extract concentration groups was $100 \%$. By observing the morphological differences of coral polyps after infection by ciliates, the length of coral polyps was $0.00 \mathrm{~cm}$, and the polyps were completely retracted into the corallites. The polyp length of each treatment group was the longest, $1.00 \pm 0.20 \mathrm{~cm}$, at $1500 \mathrm{ppm}$ treatment, which was 10 times worse than 10,000 ppm. The zooxanthellae density was the highest in the treatment group of 1500-5000 ppm, which was 20.32 times higher than that of $C$. Chlorophyll a also had the highest content in the 1500-5000 ppm treatment group, which was 8.52 times higher than that of $C$.

Table 4. Clove extract for ciliate disease treatment evaluation.

\begin{tabular}{|c|c|c|c|c|}
\hline $\begin{array}{l}\text { Treatments } \\
\text { (ppm) }\end{array}$ & $\begin{array}{l}\text { Zooxanthellae } \\
\left(\text { Cells } \times 10^{7} \mathrm{~m}^{-2}\right)\end{array}$ & $\begin{array}{l}\text { Chlorophyll a } \\
\quad\left(\mu \mathrm{g} \mathrm{cm}^{-2}\right)\end{array}$ & $\begin{array}{l}\text { Polyp Length } \\
\text { (cm/polyp) }\end{array}$ & $\underset{(\%)}{\text { Survival Rate }}$ \\
\hline $\mathrm{C}$ & $0.23 \pm 0.15^{b}$ & $5.53 \pm 0.12^{c}$ & $0.00 \pm 0.00^{\mathrm{e}}$ & $11.35 \pm 5.73^{b}$ \\
\hline 1500 & $5.03 \pm 0.50^{a}$ & $50.21 \pm 4.35^{\mathrm{a}}$ & $1.00 \pm 0.20^{\mathrm{a}}$ & $100 \pm 0.00^{\mathrm{a}}$ \\
\hline 2500 & $4.43 \pm 0.42^{\mathrm{a}}$ & $48.24 \pm 2.55^{\mathrm{a}}$ & $0.50 \pm 0.21^{b}$ & $100 \pm 0.00^{a}$ \\
\hline 5000 & $4.56 \pm 1.04^{\mathrm{a}}$ & $43.00 \pm 4.52^{\mathrm{a}}$ & $0.20 \pm 0.00^{\mathrm{c}}$ & $100 \pm 0.00^{\mathrm{a}}$ \\
\hline 7000 & $3.51 \pm 1.21^{\mathrm{ab}}$ & $32.25 \pm 3.20^{b}$ & $0.10 \pm 0.00^{\mathrm{d}}$ & $100 \pm 0.00^{\mathrm{a}}$ \\
\hline 10,000 & $3.23 \pm 0.05^{b}$ & $30.02 \pm 3.54^{b}$ & $0.10 \pm 0.00^{\mathrm{d}}$ & $100 \pm 0.00^{a}$ \\
\hline
\end{tabular}

Different letters indicate significant differences among groups in Duncan's multiple range test $(p<0.05)$. Values are expressed as means \pm SDs $(n=30$ colonies). C: control group.

\subsubsection{Evaluation of the Treatment's Response to G. columna Stress}

After the P. lucinda were infected, we used the clove extract to dip for $10 \mathrm{~min}$, and after $72 \mathrm{~h}$, the superoxide dismutase and catalase activities in the G. columna were as shown in Figure 2. The activity of $1.98 \pm 0.09 \mathrm{U} / \mathrm{mg}$ protein at $1500 \mathrm{ppm}$ was low, and the activity of $\mathrm{SOD}$ reached $8.27 \pm 0.93 \mathrm{U} / \mathrm{mg}$ protein at $5000 \mathrm{ppm}$, which was the highest. The difference between the two was 4.18 times. The SOD activities of the $7500-10,000 \mathrm{ppm}$ groups were $8.33 \pm 0.67 \mathrm{U} / \mathrm{mg}$ protein and $9.12 \pm 0.64 \mathrm{U} / \mathrm{mg}$ protein, respectively. Compared with the 1500 ppm group, it increased by 4.21 times and 4.61 times, respectively. CTA activity was lower at $1500 \mathrm{ppm}$, and CAT activity was 2.31 times lower than that of infected C. Furthermore, the 5000, 7000, and 10,000 ppm treatment group CAT activity increased by 
3.15, 3.27, and 3.31 times compared with 1500 ppm group, respectively. Therefore, the higher the concentration of clove extract, the greater the impact on the stress response of G. columna.

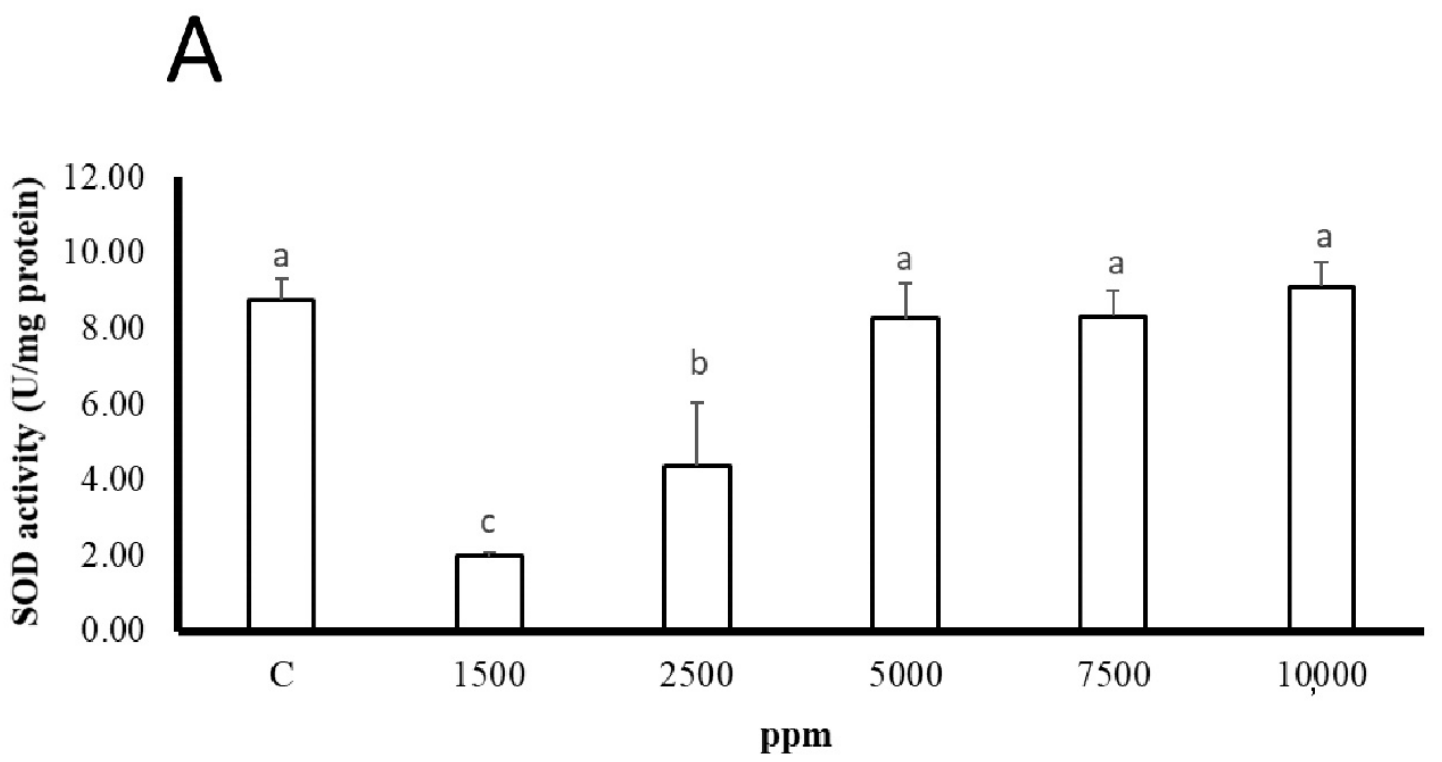

\section{B}

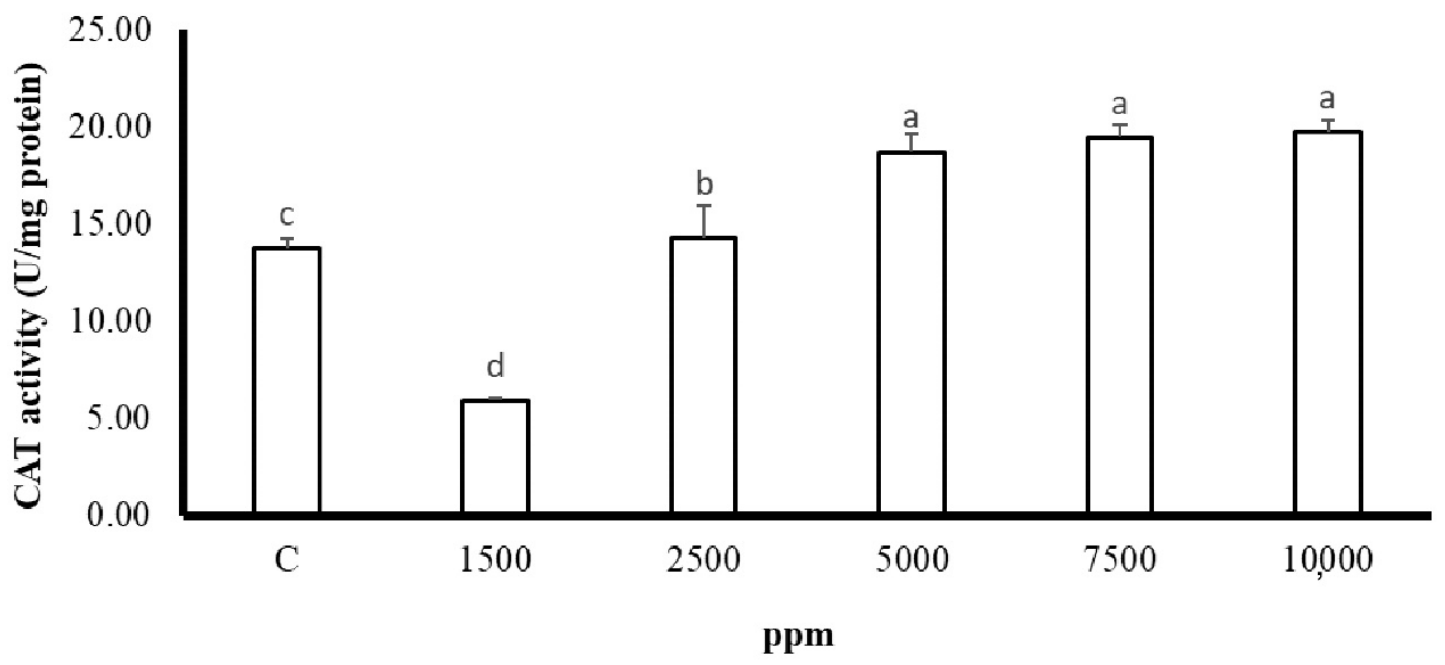

Figure 2. Changes to coral antioxidant enzymes activity during ciliate disease treatment. C: infected; clove extract was not used. Different letters indicate significant differences among groups $(p<0.05)$. Values are expressed as means \pm SDs ( $n=30$ colonies): (A) SOD, (B) CAT.

\subsubsection{The Impact to Coral Tissue}

The tissue changes after treatment with clove extract are shown in Figure 3. This study was based on Work and Meteyer (2014) [42] to judge the damage to coral tissue. The coral structure consisted of the simple structures of ectoderm, mesoglea, and endoderm. Ciliates will cause serious damage to the endoderm after infecting G. columna, and the damaged tissue will produce a vacuum. From the tissue slice, it can be observed that the infected endoderm tissue contained ciliates. When the ciliates parasitize the endoderm, they swallow the coral's zooxanthellae and tissues, resulting in tissue damage and empty vacuola. Healthy tissues do not contain a vacuum. After using the clove extract at 1500 ppm and 
dipping for $10 \mathrm{~min}$, no ciliates were found in the tissue, and no tissue damage was observed.
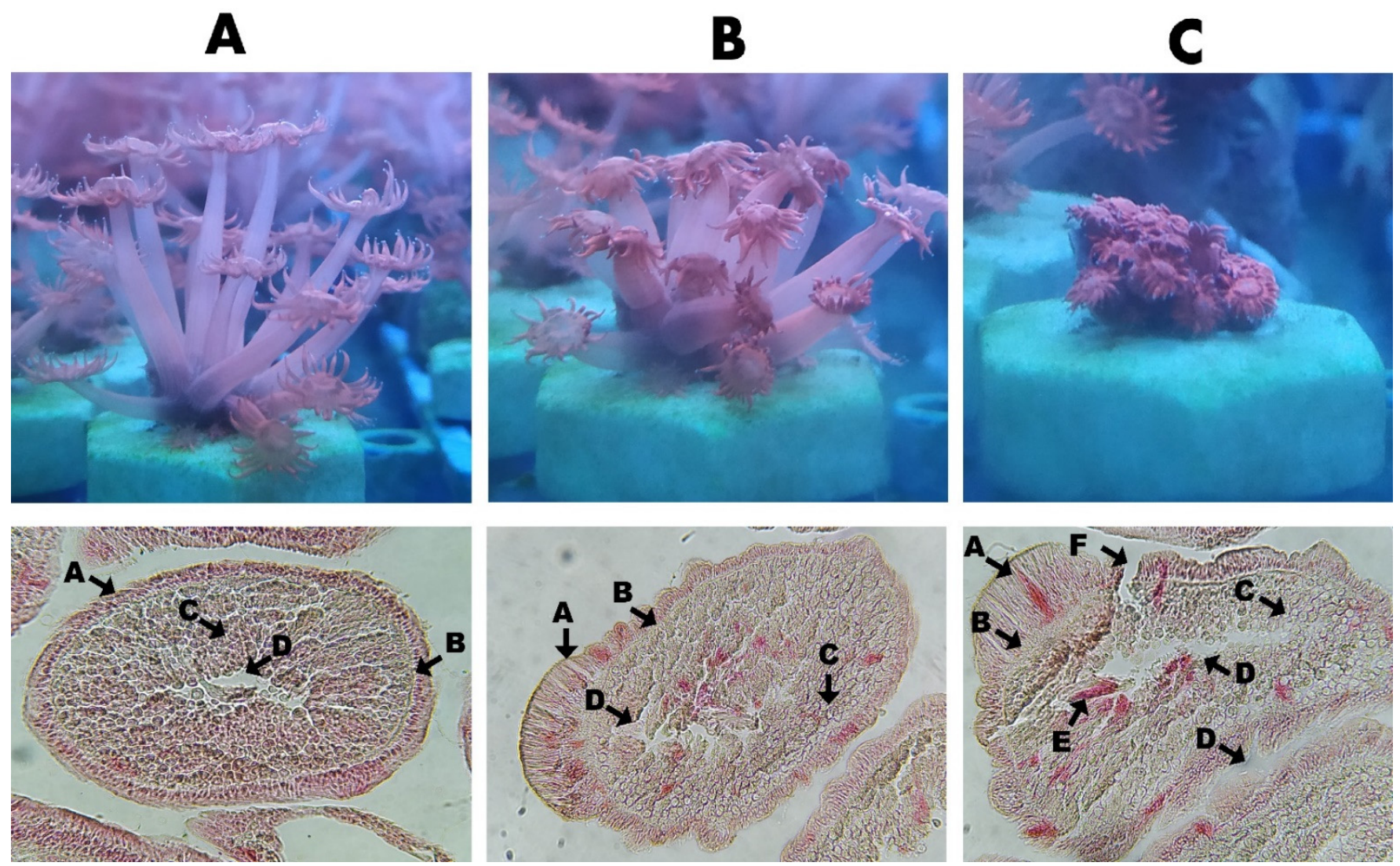

Figure 3. Image and tissue section observation of G. columna infected with ciliates and treatment with clove extract. (A) No infection. Polyps fully stretched, no tissue damage (A, ectoderm; B, mesoglea; $\mathrm{C}$, endoderm and zooxanthellae; D, stomach). (B): After being infected with ciliates, dipping was performed with $1500 \mathrm{ppm}$ clove extract for $10 \mathrm{~min}$. Coral polyps atrophied slightly, and the mesoglea and endoderm were not infected by ciliates. The endoderm contains the corpses left by the death of the ciliates (A, ectoderm; B, mesoglea; C, endoderm and zooxanthellae; D, stomach). (C): C group. Ciliates parasitize the endoderm and swallow zooxanthellae, causing serious damage to cells and tissues (A, ectoderm; B, mesoglea; C, endoderm and zooxanthellae; D, damaged tissue will produce a vacuum; E, P. Lucinda; F, ciliates infection causes damage to the tissues of the ectoderm, mesoglea and endoderm).

\section{Discussion}

Few previous studies have explored coral diseases and treatments, and the treatment of coral diseases is quite important for marine aquarium and large-scale coral aquaculture [10]. According to 18S rRNA and morphology observations, the purified ciliates in this experiment are P. Lucinda. Our discovery of ciliate GenBank matches up to $100 \%$ with the P. lucinda DNA sequence found in the Caribbean Sea $[10,16]$. This kind of ciliate infects G. columna and Euphyllia glabrescens, and causes coral festering and death [10]. This poses a serious threat to wild coral reefs and large-scale coral aquaculture.

Although we recently published that $\mathrm{KCl}$ or $\mathrm{H}_{2} \mathrm{O}_{2}$ can be used to achieve effective treatment of ciliate infections, it was found that $\mathrm{KCl}$ or $\mathrm{H}_{2} \mathrm{O}_{2}$ stimulation reduced the zooxanthellae and affected the color of corals [10]. After using $\mathrm{H}_{2} \mathrm{O}_{2}$ treatment, the length of polyps was shortened by 19.30 times, and the number of zooxanthellae also decreased significantly [10]. Therefore, if a milder natural medicine can be found for treatment, it will alleviate the corals' stress response. 
This study found that 1500 ppm of clove extract caused the death of ciliates in $300 \mathrm{~s}$, and the higher the concentration, the faster the death rate. When the concentration reached 5000 ppm, the ciliates died completely within 60 s. Previous studies have indicated that clove oil will not affect the coral color or photosynthetic efficiency at $0.5 \mathrm{ppt}$, but it will kill corals immediately at 50 ppt [19]. In addition, clove oil contains eugenol and $\beta$ caryophyllene, which can be used to remove ciliates during the purification and cultivation of microalgae [25]. Clove oil can also be used as attract-and-kill treatment against Bactrocera dorsalis [43]. Therefore, according to the experimental results, it is feasible to use clove extract for the treatment of ciliate disease in coral.

According to Frisch et al. (2007), the use of a clove oil-ethanol mixture $(10 \%$ clove oil) can cause $P$. damicornis to albinize and die. Compared with the control group without the addition of ethanol or lower exposure $(10 \mathrm{~mL})$, no coral bleaching or death was found [19]. This indicates that the mixture produced by the interaction of clove oil and ethanol was more toxic to corals [32]. The results of this experiment show that after dipping in 5000-10,000 ppm of clove extract for $10 \mathrm{~min}$, the activities of SOD and CAT both increased significantly, and the higher the concentration, the higher the activity of antioxidant enzymes, and the shorter the polyp length of each treatment group, but there was no significant difference between chlorophyll a and zooxanthellae, and no coral bleaching or death was found. When the dipping time was extended to $24 \mathrm{~h}$, the corals in the treatment groups above 5000 ppm died. Therefore, long-term dipping in clove extract will cause G. columna death, while using 1500 ppm for a short time of 10 min was effective. Soaking will not cause coral casualties. The polyp length, CAT, and SOD activities had no significant changes compared with the control group. Previous studies found that the superoxide dismutase and catalase activities of $\mathrm{KCl} \mathrm{1.5 \%} \mathrm{treatment} \mathrm{were} 3.51$ times lower than those of $\mathrm{H}_{2} \mathrm{O}_{2} 1.5 \%$, but the SOD and CAT activities of the $\mathrm{KCl} 1.5 \%$ treatment were at least 1 time higher than those of the control group without additions [10]. The results of this study showed that there was no significant change in SOD and CAT activity compared with the control group after $10 \mathrm{~min}$ of treatment with clove extract at $1500 \mathrm{ppm}$. Therefore, clove extract is more suitable for the treatment of coral ciliate disease than $\mathrm{KCl}$ and $\mathrm{H}_{2} \mathrm{O}_{2}$.

A previous study found that, after five weeks of cultivation using $14 \%$ clove oil in a lagoon for 3 days, the growth of Acropora striata, Pocillopora verrucosa, and Porites australiensis decreased by an average of 30-40\%, and the chance of coral bleaching increased by $20-80 \%$ [32]. Exposing P. verrucosa in Scleractinaire to a 50\% clove oil-ethanol solution for 1 min will cause 100\% bleaching [44]. In addition, clove oil often uses ethanol as a solvent. If clove oil is dissolved in ethanol, it will cause a more serious bleaching of corals [32]. This may be because ethanol increases the solubility of clove oil in seawater or produces toxic compounds that will harm corals [32]. This may increase the permeability of clove oil in coral tissues. Therefore, this study used sterile seawater as the solvent for the clove extract, and did not use ethanol. Soaking at 5000 ppm for $24 \mathrm{~h}$ will cause coral death, while soaking for 10 min will not cause coral death and can effectively treat ciliate disease. Cheng et al. (2021) [10] found that the use of $\mathrm{KCl}$ or $\mathrm{H}_{2} \mathrm{O}_{2}$ for ciliate disease treatment reduced the number of zooxanthellae in the coral endoderm, resulting in a dull or white coral color. Although it can be restored after a period of time, it will affect the coral's viewing value for a short time. After $10 \mathrm{~min}$ of a one-time treatment with clove extract 1500 ppm, the coral configuration, zooxanthellae, and chlorophyll a were not significantly changed after one week. Therefore, clove extract can only be used as a short-term medicinal bath or in simple use. It will not cause a stress response in the coral or cause configuration changes within 10 min of soaking, but long-term soaking will cause the coral to die.

\section{Conclusions}

According to the experimental results, clove extract can be used in the treatment of coral ciliates. According to $\mathrm{LC}_{50}$, antioxidant enzyme activity and morphological observations after treatment, it is estimated that the appropriate concentration is about $1500 \mathrm{ppm}$, and a medicated bath can achieve effective prevention and treatment within $10 \mathrm{~min}$. This 
concentration will not cause the coral to produce a strong stress response, nor will it cause coral bleaching, death, or color change. It can be used in marine aquarium and coral large-scale aquaculture. This technology has been practically applied in the Taiwan Coral King coral farm for the medication of drug-sensitive corals. It is hoped that this research can contribute to large-scale coral aquaculture and the sustainable development of wild coral reefs.

Author Contributions: Conceptualization, D.-S.D., C.-M.C. and T.-W.C.; methodology, D.-S.D.; software, W.-T.S.; validation, Y.-R.C. and C.-D.D.; formal analysis, D.-S.D., W.-T.S.; investigation, D.-S.D.; resources, D.-S.D., C.-D.D. and C.-H.P.; data curation, D.-S.D.; writing-original draft preparation, D.-S.D., W.-T.S., C.-M.C. and T.-W.C.; writing-review and editing, D.-S.D., C.-M.C.; visualization, D.-S.D., C.-H.C.; supervision, C.-H.P., T.-W.C. and C.-D.D.; project administration, D.-S.D., Y.-R.C. All authors have read and agreed to the published version of the manuscript.

Funding: This research received no external funding.

Institutional Review Board Statement: All standard national and international ethical guidelines dealing with coral handling, challenge, and sampling were fully adopted by the research team (authors). The G. columna colonies used in this experiment were obtained from Taiwan Coral King coral farm (Kaohsiung, Taiwan), a CITES-certified legal coral farm (CITES No. FTS507W0153796).

Informed Consent Statement: Not applicable.

Data Availability Statement: Not applicable.

Acknowledgments: The authors are grateful to Taiwan Coral King coral farm (Kaohsiung, Taiwan) for providing coral samples.

Conflicts of Interest: The authors declare no conflict of interest.

\section{References}

1. Acosta, A. Disease in zoanthids: Dynamics in space and time. In The Ecology and Etiology of Newly Emerging Marine Diseases; Springer: Dordrecht, The Netherlands, 2001; pp. 113-130.

2. Harvell, C.D.; Mitchell, C.E.; Ward, J.R.; Altizer, S.; Dobson, A.P.; Ostfeld, R.S.; Samuel, M.D. Climate warming and disease risks for terrestrial and marine biota. Science 2002, 296, 2158-2162. [CrossRef]

3. Bourne, D.G.; Boyett, H.V.; Henderson, M.E.; Muirhead, A.; Willis, B.L. Identification of a ciliate (Oligohymenophorea: Scuticociliatia) associated with brown band disease on corals of the Great Barrier Reef. Appl. Environ. Microbiol. 2008, 74, 883-888. [CrossRef]

4. Cróquer, A.; Bastidas, C.; Lipscomb, D. Folliculinid ciliates: A new threat to Caribbean corals? Dis. Aquat. Org. 2006, 69, 75-78. [CrossRef]

5. Sweet, M.J.; Croquer, A.; Bythell, J.C. Experimental antibiotic treatment identifies potential pathogens of white band disease in the endangered Caribbean coral Acropora cervicornis. Proc. R. Soc. B Biol. Sci. 2014, 281, 20140094. [CrossRef]

6. Winkler, R.; Antonius, A.; Abigail Renegar, D. The skeleton eroding band disease on coral reefs of Aqaba, Red Sea. Mar. Ecol. 2004, 25, 129-144. [CrossRef]

7. Randall, C.J.; Jordán-Garza, A.G.; van Woesik, R. Ciliates associated with signs of disease on two Caribbean corals. Coral Reefs 2015, 34, 243-247. [CrossRef]

8. Sweet, M.; Craggs, J.; Robson, J.; Bythell, J. Assessment of the microbial communities associated with white syndrome and brown jelly syndrome in aquarium corals. J. Zoo Aquar. Res. 2013, 1, 20-27.

9. Bourne, D.G.; Ainsworth, T.D.; Pollock, F.J.; Willis, B.L. Towards a better understanding of white syndromes and their causes on Indo-Pacific coral reefs. Coral Reefs 2015, 34, 233-242. [CrossRef]

10. Cheng, C.-M.; Cheng, Y.-R.; Ding, D.-S.; Chen, Y.-T.; Sun, W.-T.; Pan, C.-H. Effects of Ciliate Infection on the Activities of Two Antioxidant Enzymes (SOD and CAT) in Captive Coral (Goniopora columna) and Evaluation of Drug Therapy. Biology 2021, 10, 1216. [CrossRef]

11. Willis, B.L.; Page, C.A.; Dindsdale, E.A. Coral disease in the Great Barrier Reef. In Coral Health and Disease; Rosenberg, E., Loya, Y., Eds.; Springer: Berlin/Heidelberg, Germany, 2004.

12. Rodríguez, S.; Croquer, A.; Guzmán, H.M.; Bastidas, C. A mechanism of transmission and factors affecting coral susceptibility to Halofolliculina sp. infection. Coral Reefs 2009, 28, 67-77. [CrossRef]

13. Katz, S.M.; Pollock, F.J.; Bourne, D.G.; Willis, B.L. Crown-of-thorns starfish predation and physical injuries promote brown band disease on corals. Coral Reefs 2014, 33, 705-716. [CrossRef]

14. Ulstrup, K.E.; Kühl, M.; Bourne, D.G. Zooxanthellae harvested by ciliates associated with brown band syndrome of corals remain photosynthetically competent. Appl. Environ. Microbiol. 2007, 73, 1968-1975. [CrossRef] 
15. Aronson, R.B.; Precht, W.F. White-band disease and the changing face of Caribbean coral reefs. In The Ecology and Etiology of Newly Emerging Marine Diseases; Springer: Dordrecht, The Netherlands, 2001; pp. 25-38.

16. Sweet, M.J.; Séré, M.G. Ciliate communities consistently associated with coral diseases. J. Sea Res. 2016, 113, 119-131. [CrossRef]

17. Page, C.; Willis, B. Epidemiology of skeletal eroding band on the Great Barrier Reef and the role of injury in the initiation of this widespread coral disease. Coral Reefs 2008, 27, 257-272. [CrossRef]

18. Liu, H.; Schmitz, J.C.; Wei, J.; Cao, S.; Beumer, J.H.; Strychor, S.; Cheng, L.; Liu, M.; Wang, C.; Wu, N. Clove extract inhibits tumor growth and promotes cell cycle arrest and apoptosis. Oncol. Res. Featur. Preclin. Clin. Cancer Ther. 2014, 21, 247-259. [CrossRef]

19. Frisch, A.J.; Ulstrup, K.E.; Hobbs, J.-P.A. The effects of clove oil on coral: An experimental evaluation using Pocillopora damicornis (Linnaeus). J. Exp. Mar. Biol. Ecol. 2007, 345, 101-109. [CrossRef]

20. Martini, N. Potion or Poison? Cloves. J. Prim. Health Care 2015, 7, 163. [CrossRef]

21. Soto, C.G. Clove oil as a fish anaesthetic for measuring length and weight of rabbitfish (Siganus lineatus). Aquaculture 1995, 136, 149-152. [CrossRef]

22. Taylor, P.W.; Roberts, S.D. Clove oil: An alternative anaesthetic for aquaculture. N. Am. J. Aquac. 1999, 61, 150-155. [CrossRef]

23. Harper, C. Status of clove oil and eugenol for anesthesia of fish. Aquac. Mag. 2003, 29, 41-42.

24. Munday, P.L.; Wilson, S. Comparative efficacy of clove oil and other chemicals in anaesthetization of Pomacentrus amboinensis, a coral reef fish. J. Fish Biol. 1997, 51, 931-938. [CrossRef]

25. Nguyen, T. Isolation, Identification and Ecological Control Ciliates in Microalgal Cultures. KU Leuven, Science, Biology, 2019, 53. Available online: https:/ /limo.libis.be/primo-explore/fulldisplay?docid=LIRIAS2803208\&context=L\&vid=Lirias\&search_ scope $=$ Lirias\&tab=default_tab\&lang=en_US\&fromSitemap=1 (accessed on 1 December 2021).

26. Baird, A.H.; Bhagooli, R.; Ralph, P.J.; Takahashi, S. Coral bleaching: The role of the host. Trends Ecol. Evol. 2009, 24, 16-20. [CrossRef] [PubMed]

27. Lesser, M.P. Oxidative stress in marine environments: Biochemistry and physiological ecology. Annu. Rev. Physiol. 2006, 68, 253-278. [CrossRef] [PubMed]

28. Lesser, M.; Stochaj, W.; Tapley, D.; Shick, J. Bleaching in coral reef anthozoans: Effects of irradiance, ultraviolet radiation, and temperature on the activities of protective enzymes against active oxygen. Coral Reefs 1990, 8, 225-232. [CrossRef]

29. DYKENS, J.A.; Shick, J.M.; Benoit, C.; Buettner, G.R.; Winston, G.W. Oxygen radical production in the sea anemone Anthopleura elegantissima and its endosymbiotic algae. J. Exp. Biol. 1992, 168, 219-241. [CrossRef]

30. Downs, C.; Fauth, J.E.; Halas, J.C.; Dustan, P.; Bemiss, J.; Woodley, C.M. Oxidative stress and seasonal coral bleaching. Free Radic. Biol. Med. 2002, 33, 533-543. [CrossRef]

31. Higuchi, T.; Fujimura, H.; Arakaki, T.; Oomori, T. Activities of antioxidant enzymes (SOD and CAT) in the coral Galaxea fascicularis against increased hydrogen peroxide concentrations in seawater. In Proceedings of the 11th International Coral Reef Symposium, Fort Lauderdale, FL, USA, 7-11 July 2008; pp. 926-930.

32. Boyer, S.; White, J.; Stier, A.; Osenberg, C. Effects of the fish anesthetic, clove oil (eugenol), on coral health and growth. J. Exp. Mar. Biol. Ecol. 2009, 369, 53-57. [CrossRef]

33. Ding, D.-S.; Sun, W.-T.; Pan, C.-H. Feeding of a Scleractinian Coral, Goniopora columna, on Microalgae, Yeast, and Artificial Feed in Captivity. Animals 2021, 11, 3009. [CrossRef]

34. Wang, C.; Pan, X.; Fan, Y.; Chen, Y.; Mu, W. The oxidative stress response of oxytetracycline in the ciliate Pseudocohnilembus persalinus. Environ. Toxicol. Pharmacol. 2017, 56, 35-42. [CrossRef]

35. Liñán-Cabello, M.A.; Flores-Ramírez, L.A.; Zenteno-Savin, T.; Olguín-Monroy, N.O.; Sosa-Avalos, R.; Patiño-Barragan, M.; Olivos-Ortiz, A. Seasonal changes of antioxidant and oxidative parameters in the coral Pocillopora capitata on the Pacific coast of Mexico. Mar. Ecol. 2010, 31, 407-417.

36. Bradford, M.M. A rapid and sensitive method for the quantitation of microgram quantities of protein utilizing the principle of protein-dye binding. Anal. Biochem. 1976, 72, 248-254. [CrossRef]

37. Main, W.; Ross, C.; Bielmyer, G. Copper accumulation and oxidative stress in the sea anemone, Aiptasia pallida, after waterborne copper exposure. Comp. Biochem. Physiol. Part C Toxicol. Pharmacol. 2010, 151, 216-221. [CrossRef]

38. Levy, O.; Dubinsky, Z.; Achituv, Y. Photobehavior of stony corals: Responses to light spectra and intensity. J. Exp. Biol. 2003, 206, 4041-4049. [CrossRef]

39. Titlyanov, E.; Titlyanova, T.; Yamazato, K.; Van Woesik, R. Photo-acclimation of the hermatypic coral Stylophora pistillata while subjected to either starvation or food provisioning. J. Exp. Mar. Biol. Ecol. 2001, 257, 163-181. [CrossRef]

40. Jeffrey, S.T.; Humphrey, G. New spectrophotometric equations for determining chlorophylls a, b, $\mathrm{c} 1$ and c2 in higher plants, algae and natural phytoplankton. Biochem. Physiol. Pflanz. 1975, 167, 191-194. [CrossRef]

41. Sterud, E.; Hansen, M.K.; Mo, T.A. Systemic infection with Uronema-like ciliates in farmed turbot, Scophthalmus maximus (L.). J. Fish Dis. 2000, 23, 33-37. [CrossRef]

42. Work, T.; Meteyer, C. To understand coral disease, look at coral cells. EcoHealth 2014, 11, 610-618. [CrossRef] [PubMed]

43. Chuang, Y.-Y.; Hou, R.F. Effectiveness of attract-and-kill systems using methyl eugenol incorporated with neonicotinoid insecticides against the oriental fruit fly (Diptera: Tephritidae). J. Econ. Entomol. 2008, 101, 352-359. [CrossRef] [PubMed]

44. Mulochau, T.; Durville, P. Effects of a clove oil-ethanol solution on the coral Pocillopora verrucosa. Revue Ecol. 2004, 59, 425-432. 